\title{
Water-Soluble Inorganic Ions in Fine Particulate Emission During Forest Fires in Chinese Boreal and Subtropical Forests: An Indoor Experiment
}

\author{
Yuanfan Ma ${ }^{1}$, Mulualem Tigabu ${ }^{1,2}{ }^{\mathbb{D}}$, Xinbin Guo ${ }^{1}$, Wenxia Zheng ${ }^{1}$, Linfei Guo ${ }^{1}$ and \\ Futao Guo ${ }^{1, *(D)}$ \\ 1 College of Forestry, Fujian Agriculture and Forestry University, Fuzhou 350002, China; \\ 17746076057@163.com (Y.M.); mulualem.tigabu@slu.se (M.T.); guo18959151730@126.com (X.G.); \\ ZWX15985703227@163.com (W.Z.); 18120894053@163.com (L.G.) \\ 2 Southern Swedish Forest Research Centre, Swedish University of Agricultural Sciences, Box 49, \\ SE-230 52 Alnarp, Sweden \\ * Correspondence: guofutao@126.com; Tel.: +86-591-8378-0261
}

Received: 2 October 2019; Accepted: 4 November 2019; Published: 6 November 2019

\begin{abstract}
Understanding of the characteristics of water-soluble inorganic ions (WSI) in fine particulate matter $\left(\mathrm{PM}_{2.5}\right)$ emitted during forest fires has paramount importance due to their potential effect on ecosystem acidification. Thus, we investigated the emission factors (EFs) of ten most common WSI from combustion of leaves and branches of ten dominant tree species in Chinese boreal and sub-tropical forests under smoldering and flaming combustion stages using a self-designed combustion unit. The results showed that $\mathrm{EF}$ of $\mathrm{PM}_{2.5}$ was three times higher for the boreal $(6.83 \pm 0.67 \mathrm{~g} / \mathrm{kg})$ than the subtropical forest $(1.97 \pm 0.34 \mathrm{~g} / \mathrm{kg})$, and coniferous species emitted 1.5 times more $\mathrm{PM}_{2.5}$ $(5.35 \pm 0.64 \mathrm{~g} / \mathrm{kg})$ than broadleaved species $(3.45 \pm 0.37 \mathrm{~g} / \mathrm{kg})$. EF of total WSI was $1.27 \pm 0.08 \mathrm{~g} / \mathrm{kg}$ for the boreal and $1.08 \pm 0.07 \mathrm{~g} / \mathrm{kg}$ for the subtropical forest and $1.28 \pm 0.09$ and $1.07 \pm 0.06 \mathrm{~g} / \mathrm{kg}$ for broadleaved and coniferous species, respectively. Individual ionic species also varied significantly between forest types and species within forest types, and $\mathrm{K}^{+}$and $\mathrm{Cl}^{-}$were the dominant ionic species in $\mathrm{PM}_{2.5}$, accounting for $25 \%$ and $30 \%$ for the boreal forest and $23 \%$ and $27 \%$ for the subtropical forest, respectively. Emissions of $\mathrm{NO}_{2}{ }^{-}$and $\mathrm{SO}_{4}{ }^{2-}$ were the lowest, accounting for $3 \%$ and $5 \%$ for the boreal forest and $4 \%$ for each of the subtropical forests, respectively. Combustion of leaves emitted significantly more ionic species $(1.29 \pm 0.05 \mathrm{~g} / \mathrm{kg})$ than branches $(1.05 \pm 0.07 \mathrm{~g} / \mathrm{kg})$, and smoldering consistently emitted more ionic species $(1.49 \pm 0.09 \mathrm{~g} / \mathrm{kg})$ than flaming combustion $(0.88 \pm 0.03 \mathrm{~g} / \mathrm{kg})$. The cation to anion ratio was $\geq 1.0$, suggesting that the particulate matter is neutral to alkalescent. As a whole, our findings demonstrate that forest fire in these regions may not contribute to ecosystem acidification despite the emission of a considerable amount of WSI during forest fires.
\end{abstract}

Keywords: acid rain; aerosol; biomass burning; forest fire; PM2.5

\section{Introduction}

Forest fire releases a large volume of smoke into the atmospheric environment, accounting for up to $42 \%$ of biomass-burning particulate emissions [1]. The smoke released from biomass-burning is mainly composed of particulate matter (PM) of different aerodynamic diameter, of which PM with a diameter less than $2.5 \mu \mathrm{m}\left(\mathrm{PM}_{2.5}\right)$ accounts for more than $90 \%$ of the total PM emitted from biomass combustion [2]. The PM derived from biomass-burning consists of condensed hydrocarbons, a mixture of elemental carbon and water soluble inorganic ionic species.

There is a growing concern about the emission of water-soluble inorganic ions, such as ammonium, nitrate, sulfate, and chloride, in PM emissions, as they modify the degree of acidity of the PM; 
thereby resulting in acidification of ecosystems and contributing to the visibility reduction by light scattering [3,4]. Acid deposition and/or acid rain have a considerable impact on growth and productivity of forest and other ecosystems [5] by increasing foliar damage and soil acidity by acid water. The potential effects of acid rain on plants include foliar damage, disturbance to normal metabolic processes, inhibition of seed germination and seedling growth and predisposing the plants to other environmental stress factors [6,7]. Thus, characterizing water-soluble inorganic ions in atmospheric aerosol from mixed sources of emission has been a subject of many studies [3,4,8-10]. However, studies characterizing water-soluble inorganic ions in PM emitted from woody biomass burning are limited, particularly in China [11-13], where large forest fires occur annually. Given the predicted increase in the frequency and severity of forest fires in different parts of the globe as a consequence of climate change and vegetation encroachment, it is of paramount importance to understand the characteristics of water-soluble ions in PM emitted during forest fires.

Thus, the present study investigated the emissions of ten common water-soluble inorganic ions $\left(\mathrm{Na}^{+}, \mathrm{NH}_{4}{ }^{+}, \mathrm{K}^{+}, \mathrm{Mg}^{2+}\right.$ and $\mathrm{Ca}^{2+}$ as well as $\mathrm{F}^{-}, \mathrm{Cl}^{-}, \mathrm{NO}_{3}{ }^{-}, \mathrm{NO}_{2}{ }^{-}$and $\left.\mathrm{SO}_{4}{ }^{2-}\right)$ in $\mathrm{PM}_{2.5}$ from burning of leaves and branches of ten main tree species from boreal and subtropical forests of China under two combustion states, smoldering vis-à-vis flaming. The Chinese boreal and sub-tropical forest ecosystems are among China's four major forest management regions. The sub-tropical region, located in southern China, is an area that experiences high annual forest fire incidence, with nearly 15,000 forest fires occurring from 2000 to 2010 [14]. The Chinese boreal forest in northeastern China is prone to frequent wildfires [15,16] and has the largest average annual burned area in China, 1,300,000 ha between 1980 and 2005 [17].

The main objective of the study was to evaluate whether forest fire contributes to acidity of fine $\mathrm{PM}$ by characterizing the water-soluble composition of $\mathrm{PM}_{2.5}$ emitted from forest fire according to combustion condition, fuel typologies, and forest type. The study specifically addressed the following questions: (1) Does emission of water-soluble ions vary among species and between forest types? (2) Does emission of water-soluble ions vary with fuel typologies, i.e., leaves versus branches, which are the common fuels during surface fire? (3) Does emission of water-soluble ions vary with combustion state, flaming versus smoldering? and (4) Is there a relationship between anions and cations in water-soluble ions? The emission of $\mathrm{PM}_{2.5}$ has been shown to vary with tree species and combustion conditions, as more $\mathrm{PM}_{2.5}$ is emitted during the smoldering stage, leaves release more $\mathrm{PM}_{2.5}$ than branches, and conifer trees emit more $\mathrm{PM}_{2.5}$ than broad-leaved trees [13]. Thus, it was hypothesized that the emission of water-soluble inorganic ions may vary among tree species, between forest type and combustion condition.

\section{Materials and Methods}

\subsection{Samples and Collection of $P M_{2.5}$}

A total of ten main tree species that are common in the boreal and subtropical forests of China, five from each forest type, were selected. The coniferous tree species included Larix gmelinii (Rupr.) Kuzen. and Pinus sylvestris var. mongolica Litv from the boreal forest region and Pinus massoniana L. and Cunninghamia lanceolata L. from the subtropical forest region. The broadleaved species from the boreal forest region included Betula platyphylla Suk., Quercus mongolica Fisch. ex Ledeb and Populus davidiana L. while those from the subtropical forest region were Cinnamomum camphora L., Eucalyptus robusta Smith, and Phoebe bournei (Hemsl.) Yang. Leaves and branches from these species were collected from the Nanying research station, Daxing' an mountains and the research forest of Fujian Agriculture and Forestry University in July and October, 2017, and the samples were evenly mixed and air-dried at a controlled relative humidity of $40 \%$ for three days until constant mass to avoid the confounding effect of seasonal variations in moisture and photosynthesis on the chemical composition of samples. All targeted trees were selected far away from the urban area to mitigate the influence of urban air pollutants. In addition, the branches and leaves of the same tree species were collected from different 
individual trees to ensure consistency of samples, and the samples were then mixed. The branch and leaf samples were then divided into three replicates (testing samples) using a 1/1000 electronic balance (50 g per testing sample).

The indoor combustion experiments were conducted by using a self-designed biomass combustion unit (Figure 1; [18]). The combustion device consists of a combustion chamber, temperature controller, flue gas analyzer, particle analyzer and sampler, and other additional components. The Flue Gas Analyzer (Testo350, Testo Instruments International Trading Co., Ltd., Lenzkirch, Germany) determines the pollutants in the flue gas based on infrared on-line monitoring and requires calibration with standard gas before each experiment. The calibrated instrument was used to identify the background concentrations of pollutants in the combustion chamber, which were recorded and then deducted from the final results. The instrument has a recording interval of $5 \mathrm{~s}$, and the sensitivity of the instrument is $0.01 \%$ for $\mathrm{CO}_{2}$ and 1 ppm for $\mathrm{CO}, \mathrm{CH}$ and $\mathrm{NO}_{\mathrm{x}}$. The fine particulate matter $\left(\mathrm{PM}_{2.5}\right)$ was monitored using a particle analyzer (TSI8533, TSI Incorporated, Shoreview, MN, USA) throughout the combustion process, which works based on infrared on-line monitoring and requires calibration with standard gas. Background concentration identification is also required. The instrument has a recording interval of $5 \mathrm{~s}$, and the background concentration of $\mathrm{PM}_{2.5}$ for this experiment was $0.001 \mathrm{mg} / \mathrm{m}^{3}$. The Deployable Particulate Sampler (DPS) System (SKC Incorporated, Eighty Four, PA, USA) is ideal for ambient and indoor air sampling of $\mathrm{PM}_{2.5}$. The system includes a fully programmable Li-Ion-powered sample pump (SKC Ltd., Dorset, UK) for 24-hour sampling. The system pump provides a constant and accurate airflow with a flow rate of $10 \mathrm{~L} / \mathrm{min}$.

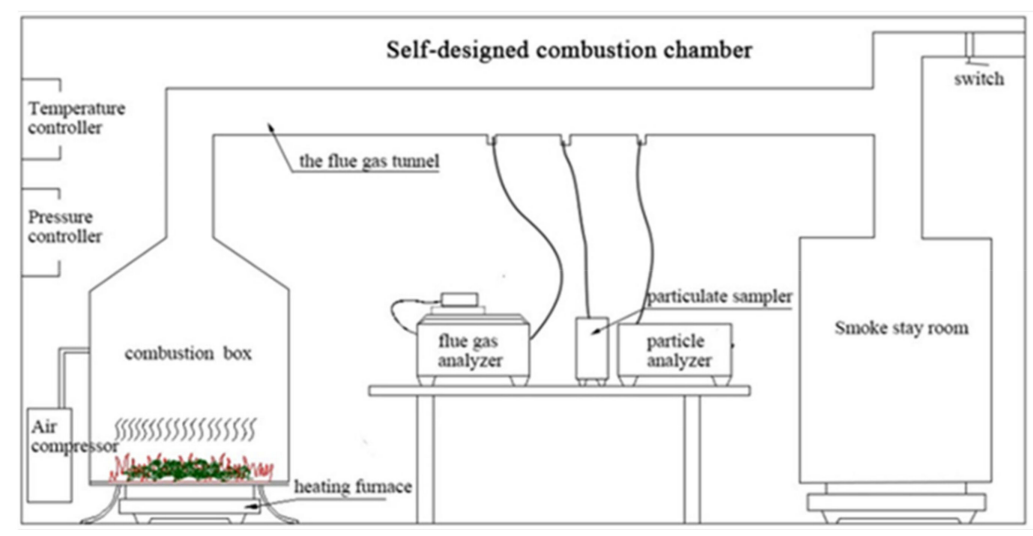

Figure 1. Schematic diagram of the self-designed biomass burning device.

Before starting the combustion test, the temperature controller was adjusted to control the temperature of the chamber to create either smoldering or flaming conditions. The combustion status was characterized by a Modified Combustion Efficiency (MCE), defined as the ratio of $\mathrm{CO}_{2}$ to the change in $\mathrm{CO}$ and $\mathrm{CO}_{2}$, calculated using the following formula:

$$
\mathrm{MCE}=\frac{\Delta \mathrm{CO}_{2}}{\Delta \mathrm{CO}+\Delta \mathrm{CO}_{2}}
$$

A combustion stage was considered as flaming when MCE reaches 0.99 and smoldering stage when MCE is between $0.65-0.85$ [19,20]. After several preliminary experiments, the smoldering temperature was controlled at around $180{ }^{\circ} \mathrm{C}$ and the flaming temperature at around $270{ }^{\circ} \mathrm{C}$. After adding samples into the combustion chamber, the flue gas analyzer and the particle analyzer were turned on for real-time monitoring, and the concentrations of various pollutants were measured and recorded within $5 \mathrm{~s}$ in order to calculate the emission factor of particulate matter and correct combustion efficiency. The particle sampler was then turned on when the combustion conditions remained stable and cooled down to room temperature. Teflon-polytetrafliuoroethylene (PTFE) membrane filters (SKC Ltd., Dorset, $\mathrm{UK})$ were used to collect $\mathrm{PM}_{2.5}$ during different combustion stages and were weighed before and 
after sample collection using a microbalance with $1 \mathrm{mg}$ sensitivity. Control experiments were also performed using blank filters. Three replicates were conducted for each sample collection and analysis.

\subsection{Extraction and Analysis of Water-Soluble Inorganic Ions}

The concentrations of five anions $\left(\mathrm{F}^{-}, \mathrm{Cl}^{-}, \mathrm{NO}_{3}{ }^{-}, \mathrm{NO}_{2}{ }^{-}\right.$and $\left.\mathrm{SO}_{4}{ }^{2-}\right)$ and five cations $\left(\mathrm{Na}^{+}\right.$, $\mathrm{NH}_{4}{ }^{+}, \mathrm{K}^{+}, \mathrm{Mg}^{2+}$ and $\mathrm{Ca}^{2+}$ ) were determined in aqueous extracts of the sample filters. To extract the water-soluble ions from the filters, the portions of the filters used for the gravimetric analysis were placed in separate $12 \mathrm{~mL}$ vials containing $10 \mathrm{~mL}$ of distilled-deionized water (18.2 $\mathrm{M} \Omega$ resistivity). The vials were placed in an ultrasonic water bath and shaken with a mechanical shaker for $1 \mathrm{~h}$ to extract the ions. The extracts were filtered through $0.45 \mu \mathrm{m}$ pore size microporous membranes, and the filtrates were stored at $4{ }^{\circ} \mathrm{C}$ in clean tubes before analysis.

A Dionex-1100 Ion Chromatograph (Dionex Inc., Sunnyvale, CA, USA) was used for determining both the cations and anions in the aqueous extracts of the air filters. For the cation analyses, the instrument was equipped with an IonPacCS12A column $(20 \mathrm{mmol} / \mathrm{L}$ methanesulfonic acid as the eluent), while an ASRS-4num column ( $25 \mathrm{mmol} / \mathrm{L} \mathrm{KOH}$ as the eluent) was used for anions. The measurements were taken under the following conditions: column temperature: $30^{\circ} \mathrm{C}$; flow rate: $1.0 \mathrm{~mL} / \mathrm{min}$; injection volume: $20 \mu \mathrm{L}$; flow precision $< \pm 0.1 \%$; flow rate maximum error $0.1 \%$. Detection limits were $4.5 \mathrm{mg} \mathrm{L}^{-1}$ for $\mathrm{Na}^{+}, 4.0 \mathrm{mg} \mathrm{L}^{-1}$ for $\mathrm{NH}_{4}{ }^{+}, 10.0 \mathrm{mg} \mathrm{L}^{-1}$ for K${ }^{+}, \mathrm{Mg}^{2+}$ and $\mathrm{Ca}^{2+}, 0.5 \mathrm{mg} \mathrm{L}^{-1}$ for $\mathrm{F}^{-}$and $\mathrm{Cl}^{-}, 15 \mathrm{mg} \mathrm{L}^{-1}$ for $\mathrm{NO}_{2}{ }^{-}$and $\mathrm{NO}_{3}{ }^{-}$, and $20 \mathrm{mg} \mathrm{L}^{-1}$ for $\mathrm{SO}_{4}{ }^{2-}$. Standard reference materials produced by the National Research Center for Certified Reference Materials (Beijing, China) were analyzed for quality control and assurance purposes. Data from blank samples were subtracted from the corresponding sample data after analysis [21].

\subsection{Calculation of Emission Factors for Water-Soluble Ions in PM2.5}

The emission factor $(\mathrm{EF})$ of a given ion is defined as the amount of this ion emitted to the atmosphere per unit mass of fuel consumed by the fire. The emission factors of particulate matter and water-soluble ions were calculated in this study using the carbon mass balance method. The specific calculation procedure can be found in Zhang et al. [22]. The carbon mass balance method offers an advantage such that it is not necessary to collect all emitted pollutants, and the sampling position in the plume is adjustable [23].

\subsection{Statistical Analysis}

Two-way analysis of variance (ANOVA) was performed to determine the significant differences in EF of $\mathrm{PM}_{2.5}$ and water-soluble inorganic ions (WSI) between forest types (boreal versus sub-tropical) and between species (conifer versus broadleaved), followed by least significant difference test for comparison of means. A $t$-test was performed to determine significant differences between species within each forest type and between combustion of leaves and branches as well as between smoldering and flaming stages of combustion. Correlation analysis between cations and anions was also conducted to examine the relationship between ionic species in $\mathrm{PM}_{2.5}$.

\section{Results}

\subsection{Emission of $P M_{2.5}$ and Water-Soluble Inorganic Ions}

The EF of $\mathrm{PM}_{2.5}$ varied significantly $(p<0.05)$ between forest types and species (Table 1$)$. The EF of $\mathrm{PM}_{2.5}$ was three times higher for the boreal $(6.83 \pm 0.67 \mathrm{~g} / \mathrm{kg})$ than the subtropical forest $(1.97 \pm 0.34 \mathrm{~g} / \mathrm{kg})$ when both coniferous and broadleaved species were burnt, and coniferous species emitted 1.5 times more $\mathrm{PM}_{2.5}(5.35 \pm 0.64 \mathrm{~g} / \mathrm{kg})$ than broadleaved species $(3.45 \pm 0.37 \mathrm{~g} / \mathrm{kg})$. However, combustion of coniferous species from the boreal forest emitted more $\mathrm{PM}_{2.5}$ than the broadleaved species and species from sub-tropical forest. Similarly, the EF of WSI exhibited significant differences between forest types and species (Table 1). The EF total WSI was higher for the boreal forest $(1.27 \pm 0.08 \mathrm{~g} / \mathrm{kg})$ than for 
the subtropical forests $(1.08 \pm 0.07 \mathrm{~g} / \mathrm{kg})$, and combustion of broadleaved species emitted more WSI $(1.28 \pm 0.09 \mathrm{~g} / \mathrm{kg})$ than coniferous species $(1.07 \pm 0.06 \mathrm{~g} / \mathrm{kg})$. Combustion of broadleaved species from the boreal forest resulted in higher EF of WSI than the coniferous species as well as species from the subtropical forest. As a whole, the EF of WSI was higher for boreal than subtropical species. The heat of combustion of leaves and branches was 19,182 $\pm 294 \mathrm{~kJ}$ and 18,319 $\pm 264 \mathrm{~kJ}$ for coniferous and broadleaved species from the boreal region, respectively. For subtropical region, it was 19,115 $\pm 286 \mathrm{~kJ}$ and $18,054 \pm 293 \mathrm{~kJ}$ for coniferous and broadleaved species, respectively (Table 1).

Table 1. Emission factors of $\mathrm{PM}_{2.5}\left(\mathrm{EF}_{\mathrm{PM} 2.5}\right)$ and water-soluble inorganic ions ( $\left.\mathrm{EF}_{\mathrm{WSI}}\right)$ released during combustion of both leaves and branches of coniferous and broadleaved species from the boreal and sub-tropical forests together with heat of combustion of fuels.

\begin{tabular}{ccccc}
\hline Forest Type & Species & EFPM2.5 $^{\left(\mathbf{g} \cdot \mathbf{k g}^{-\mathbf{1}}\right)}$ & EFWSI $_{\left.\mathbf{g} \cdot \mathbf{k g}^{-\mathbf{1}}\right)}$ & Heat of Combustion (kJ) \\
\hline \multirow{3}{*}{ Boreal } & Conifer & $9.03 \pm 0.97 \mathrm{a}$ & $1.03 \pm 0.06 \mathrm{a}$ & $19182 \pm 294 \mathrm{a}$ \\
& Broadleaved & $4.62 \pm 0.38 \mathrm{~b}$ & $1.51 \pm 0.10 \mathrm{~b}$ & $18319 \pm 264 \mathrm{~b}$ \\
& Mean & $\mathbf{6 . 8 3} \pm \mathbf{0 . 6 7 A}$ & $\mathbf{1 . 2 7} \pm \mathbf{0 . 0 8 A}$ & $18751 \pm 289 \mathrm{~A}$ \\
\hline \multirow{3}{*}{ Subtropical } & Conifer & $1.66 \pm 0.31 \mathrm{c}$ & $1.11 \pm 0.06 \mathrm{a}$ & $19115 \pm 286 \mathrm{a}$ \\
& Broadleaved & $2.28 \pm 0.37 \mathrm{c}$ & $1.05 \pm 0.09 \mathrm{a}$ & $18054 \pm 293 \mathrm{~b}$ \\
& Mean & $\mathbf{1 . 9 7} \pm \mathbf{0 . 3 4 B}$ & $\mathbf{1 . 0 8} \pm \mathbf{0 . 0 7 B}$ & $18584 \pm 290 \mathrm{~B}$
\end{tabular}

Means followed by different lower and upper case letter across the columns are significantly different between species and between the boreal and sub-tropical regions, respectively, at the $5 \%$ probability level.

With regard to the emission of individual ionic species, significant differences were observed between forest types and species for some ions (Table 2). The EF of $\mathrm{Na}^{+}, \mathrm{K}^{+}, \mathrm{Mg}^{2+}, \mathrm{Ca}^{2+}, \mathrm{Cl}^{-}$and $\mathrm{NO}_{3}^{-}$ were higher for the boreal than subtropical forest while the $\mathrm{EF}$ of $\mathrm{F}^{-}$was higher for the subtropical than boreal forest. Combustion of broadleaved species emitted more $\mathrm{Na}^{+}, \mathrm{Cl}^{-}, \mathrm{SO}_{4}{ }^{2-}$ and $\mathrm{NO}_{3}{ }^{-}$than that of coniferous species. Comparison of the EF of WSI between species within each forest type (Table 3) revealed that broadleaved species from the boreal forest emitted significantly more ions, except $\mathrm{K}^{+}$and $\mathrm{Ca}^{2+}$, than coniferous species. For the subtropical forest, combustion of coniferous species resulted in higher EF of $\mathrm{NH}_{4}{ }^{+}, \mathrm{Mg}^{2+}$ and $\mathrm{F}^{-}$than broadleaved species. The dominant water-soluble ions in $\mathrm{PM}_{2.5}$ released during burning of coniferous and broadleaved species were $\mathrm{K}^{+}$and $\mathrm{Cl}^{-}$, accounting $25 \%$ and $30 \%$ for the boreal forest and $23 \%$ and $27 \%$ for the subtropical forest, respectively. Emissions of $\mathrm{NO}_{2}{ }^{-}$ and $\mathrm{SO}_{4}{ }^{2-}$ were the lowest, accounting 3\% and 5\% for the boreal forest and $4 \%$ each for the subtropical forests, respectively. The EF of individual ionic species was in the order of $\mathrm{K}^{+}>\mathrm{Cl}^{-}>\mathrm{Ca}^{2+}>\mathrm{Na}^{+}>$ $\mathrm{NH}_{4}{ }^{+}>\mathrm{Mg}^{2+}>\mathrm{NO}_{3}{ }^{-}>\mathrm{F}^{-}>\mathrm{NO}_{2}{ }^{-}>\mathrm{SO}_{4}{ }^{2-}$ for coniferous species from the boreal region; $\mathrm{Cl}^{-}>\mathrm{K}^{+}>$ $\mathrm{Ca}^{2+}>\mathrm{Na}^{+}>\mathrm{Mg}^{2+}>\mathrm{NH}_{4}{ }^{+}>\mathrm{NO}_{3}{ }^{-}>\mathrm{F}^{-}>\mathrm{SO}_{4}{ }^{2-}>\mathrm{NO}_{2}{ }^{-}$for broadleaved species from the boreal region; $\mathrm{Cl}^{-}>\mathrm{K}^{+}>\mathrm{F}^{-}>\mathrm{NH}_{4}{ }^{+}>\mathrm{Ca}^{2+}>\mathrm{Mg}^{2+}>\mathrm{Na}^{+}>\mathrm{NO}_{2}{ }^{-}>\mathrm{SO}_{4}{ }^{2-}>\mathrm{NO}_{3}{ }^{-}$for coniferous species from the subtropical region; and $\mathrm{Cl}^{-}>\mathrm{K}^{+}>\mathrm{Ca}^{2+}>\mathrm{F}^{-}>\mathrm{SO}_{4}{ }^{2-}>\mathrm{Na}^{+}>\mathrm{NH}_{4}^{+}>\mathrm{Mg}^{2+} / \mathrm{NO}_{3}{ }^{-}>\mathrm{NO}_{2}^{-}$ for broadleaved species from the subtropical region.

Table 2. Emission factor $(\mathrm{g} / \mathrm{kg})$ of water-soluble inorganic ions in $\mathrm{PM}_{2.5}$ released during combustion of leaves and branches of coniferous and broadleaved species from the boreal and sub-tropical forests.

\begin{tabular}{ccccc}
\hline & \multicolumn{2}{c}{ Forest Type } & \multicolumn{2}{c}{ Species } \\
\hline Ions & Boreal & Subtropical & Conifer & Broadleaved \\
\hline $\mathrm{Na}^{+}$ & $0.101 \pm 0.008 \mathrm{a}$ & $0.061 \pm 0.005 \mathrm{~b}$ & $0.067 \pm 0.005 \mathrm{~A}$ & $0.091 \pm 0.008 \mathrm{~B}$ \\
$\mathrm{NH}_{4}^{+}$ & $0.083 \pm 0.009 \mathrm{a}$ & $0.073 \pm 0.006 \mathrm{a}$ & $0.076 \pm 0.006 \mathrm{~A}$ & $0.079 \pm 0.008 \mathrm{~A}$ \\
$\mathrm{~K}^{+}$ & $0.326 \pm 0.012 \mathrm{a}$ & $0.248 \pm 0.015 \mathrm{~b}$ & $0.280 \pm 0.015 \mathrm{~A}$ & $0.292 \pm 0.013 \mathrm{~A}$ \\
$\mathrm{Mg}^{2+}$ & $0.085 \pm 0.008 \mathrm{a}$ & $0.052 \pm 0.005 \mathrm{~b}$ & $0.061 \pm 0.005 \mathrm{~A}$ & $0.073 \pm 0.008 \mathrm{~A}$ \\
$\mathrm{Ca}^{2+}$ & $0.125 \pm 0.008 \mathrm{a}$ & $0.099 \pm 0.009 \mathrm{~b}$ & $0.111 \pm 0.008 \mathrm{~A}$ & $0.112 \pm 0.008 \mathrm{~A}$ \\
$\mathrm{~F}^{-}$ & $0.054 \pm 0.004 \mathrm{a}$ & $0.109 \pm 0.008 \mathrm{~b}$ & $0.080 \pm 0.009 \mathrm{~A}$ & $0.082 \pm 0.006 \mathrm{~A}$ \\
$\mathrm{Cl}^{-}$ & $0.392 \pm 0.027 \mathrm{a}$ & $0.286 \pm 0.010 \mathrm{~b}$ & $0.287 \pm 0.011 \mathrm{~A}$ & $0.374 \pm 0.023 \mathrm{~B}$ \\
$\mathrm{SO}_{4}^{-}$ & $0.043 \pm 0.004 \mathrm{a}$ & $0.062 \pm 0.010 \mathrm{a}$ & $0.033 \pm 0.004 \mathrm{~A}$ & $0.066 \pm 0.008 \mathrm{~B}$ \\
$\mathrm{NO}_{3}{ }^{-}$ & $0.071 \pm 0.009 \mathrm{a}$ & $0.041 \pm 0.004 \mathrm{~b}$ & $0.039 \pm 0.003 \mathrm{~A}$ & $0.067 \pm 0.008 \mathrm{~B}$ \\
$\mathrm{NO}_{2}^{-}$ & $0.041 \pm 0.006 \mathrm{a}$ & $0.046 \pm 0.005 \mathrm{a}$ & $0.038 \pm 0.004 \mathrm{~A}$ & $0.047 \pm 0.006 \mathrm{~A}$ \\
\hline
\end{tabular}

Means followed by different lower and upper case letters across the rows are significantly different between the boreal and sub-tropical regions and between confer and broadleaved species, respectively, at the $5 \%$ probability level. 
Table 3. Comparison of the emission factor $(\mathrm{g} / \mathrm{kg})$ of water-soluble inorganic ions in $\mathrm{PM}_{2.5}$ released from combustion of conifer and broadleaved species within each region.

\begin{tabular}{ccccc}
\hline & \multicolumn{2}{c}{ Within Boreal } & \multicolumn{2}{c}{ Within Subtropical } \\
\hline Ions & Conifer & Broadleaved & Conifer & Broadleaved \\
\hline $\mathrm{Na}^{+}$ & $0.078 \pm 0.006 \mathrm{a}$ & $0.117 \pm 0.013 \mathrm{~b}$ & $0.055 \pm 0.008 \mathrm{~A}$ & $0.064 \pm 0.006 \mathrm{~A}$ \\
$\mathrm{NH}_{4}{ }^{+}$ & $0.058 \pm 0.004 \mathrm{a}$ & $0.099 \pm 0.014 \mathrm{~b}$ & $0.094 \pm 0.009 \mathrm{~A}$ & $0.058 \pm 0.007 \mathrm{~B}$ \\
$\mathrm{~K}^{+}$ & $0.326 \pm 0.024 \mathrm{a}$ & $0.326 \pm 0.012 \mathrm{a}$ & $0.234 \pm 0.015 \mathrm{~A}$ & $0.257 \pm 0.022 \mathrm{~A}$ \\
$\mathrm{Mg}^{2+}$ & $0.057 \pm 0.004 \mathrm{a}$ & $0.103 \pm 0.012 \mathrm{~b}$ & $0.065 \pm 0.009 \mathrm{~A}$ & $0.043 \pm 0.012 \mathrm{~B}$ \\
$\mathrm{Ca}^{2+}$ & $0.129 \pm 0.011 \mathrm{a}$ & $0.122 \pm 0.011 \mathrm{a}$ & $0.093 \pm 0.012 \mathrm{~A}$ & $0.103 \pm 0.011 \mathrm{~A}$ \\
$\mathrm{~F}^{-}$ & $0.029 \pm 0.003 \mathrm{a}$ & $0.070 \pm 0.006 \mathrm{~b}$ & $0.132 \pm 0.008 \mathrm{~A}$ & $0.093 \pm 0.011 \mathrm{~B}$ \\
$\mathrm{Cl}^{-}$ & $0.275 \pm 0.018 \mathrm{a}$ & $0.470 \pm 0.037 \mathrm{~b}$ & $0.299 \pm 0.012 \mathrm{~A}$ & $0.278 \pm 0.016 \mathrm{~A}$ \\
$\mathrm{SO}_{4}{ }^{-}$ & $0.017 \pm 0.001 \mathrm{a}$ & $0.060 \pm 0.005 \mathrm{~b}$ & $0.048 \pm 0.006 \mathrm{~A}$ & $0.071 \pm 0.016 \mathrm{~A}$ \\
$\mathrm{NO}_{3}{ }^{-}$ & $0.039 \pm 0.005 \mathrm{a}$ & $0.092 \pm 0.013 \mathrm{~b}$ & $0.038 \pm 0.005 \mathrm{~A}$ & $0.043 \pm 0.006 \mathrm{~A}$ \\
$\mathrm{NO}_{2}{ }^{-}$ & $0.022 \pm 0.003 \mathrm{a}$ & $0.053 \pm 0.009 \mathrm{~b}$ & $0.053 \pm 0.006 \mathrm{~A}$ & $0.041 \pm 0.007 \mathrm{~A}$ \\
\hline
\end{tabular}

Means followed by different lower and upper case letter are significantly different between conifer and broadleaved species within the boreal and sub-tropical region, respectively, at the $5 \%$ probability level.

\subsection{EF of Water-Soluble Ions in Relation to Combustion of Leaves and Branches}

The EF of WSI varied significantly between combustion of leaves and branches of species group within each forest type (Figure 2). For coniferous species from the boreal region, combustion of leaves emitted more $\mathrm{NH}_{4}{ }^{+}, \mathrm{K}^{+}, \mathrm{Mg}^{2+}$ and $\mathrm{Ca}^{2+}$ than combustion of branches, while the EF of the rest of the ions did not differ between leaves and branches. For broadleaved species from the boreal region, significantly higher $\mathrm{NH}_{4}^{+}, \mathrm{K}^{+}, \mathrm{Ca}^{2+}$ and $\mathrm{Cl}^{-}$were emitted during combustion of leaves than branches. Combustion of leaves of coniferous species from the subtropical region emitted more $\mathrm{Na}^{+}, \mathrm{K}^{+}, \mathrm{Mg}^{2+}$ and $\mathrm{Cl}^{-}$but less $\mathrm{Ca}^{2+}$ than combustion of branches. For broadleaved species from the subtropical region, combustion of leaves resulted in higher EF of all water-soluble ions than the combustion of branches.
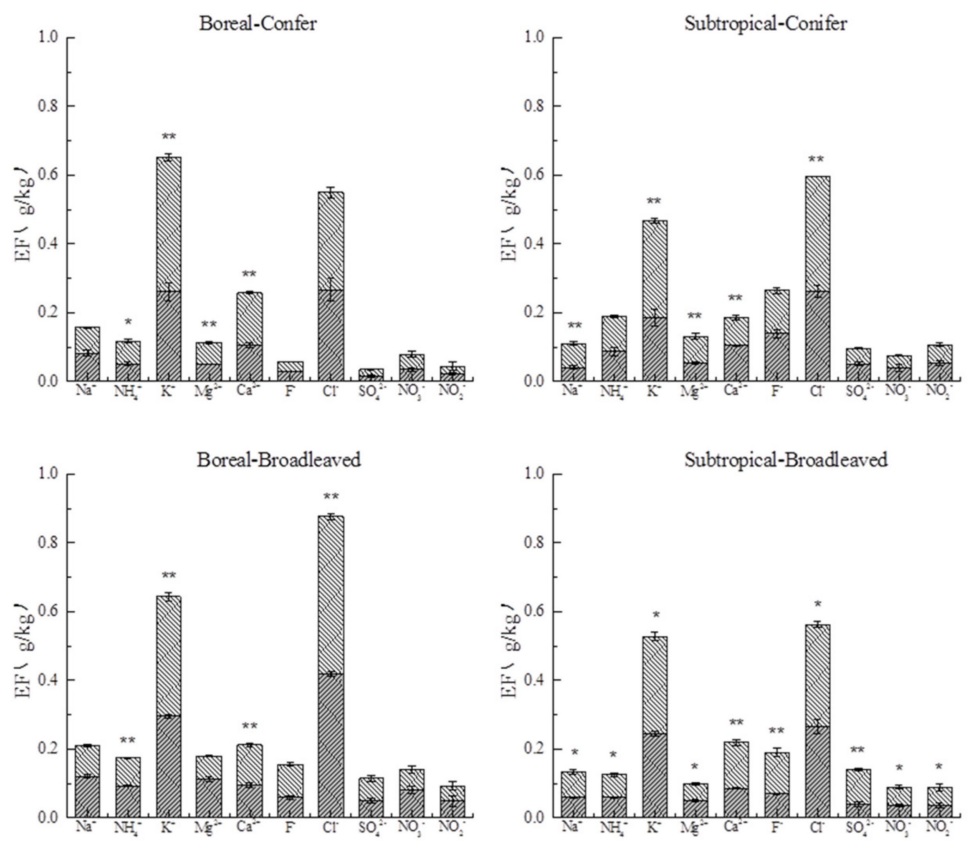

Leaf

Figure 2. Comparison of the emission factor $(\mathrm{g} / \mathrm{kg})$ of water-soluble inorganic ions in $\mathrm{PM}_{2.5}$ between combustion of leaves and branches of each group of species within each region. Bars with asterisks (** $p<0.01$ and $* p<0.05)$ indicate significant differences between leaves and branches of conifer and broadleaved species within the boreal and sub-tropical region at the $5 \%$ probability level. 


\subsection{EF of Water-Soluble Ions in $P M_{2.5}$ Emitted During Smoldering and Flaming}

For each species group within each forest type, significant differences were observed in the EF of WSI between smoldering and flaming stages of combustion $(p<0.05)$. Generally, smoldering released more WSI than flaming for most of the species (Figure 3). Smoldering resulted in significantly higher emissions of all ionic species, except $\mathrm{K}^{+}$, than flaming for coniferous species from the boreal region while EFs for all WSI were higher during smoldering than flaming stages of combustion for broadleaved species from the boreal region. While smoldering resulted in higher EFs of all WSI, except $\mathrm{Cl}^{-}$and $\mathrm{NO}_{3}{ }^{-}$, it yielded higher EFs of all WSI for coniferous species from the subtropical region.
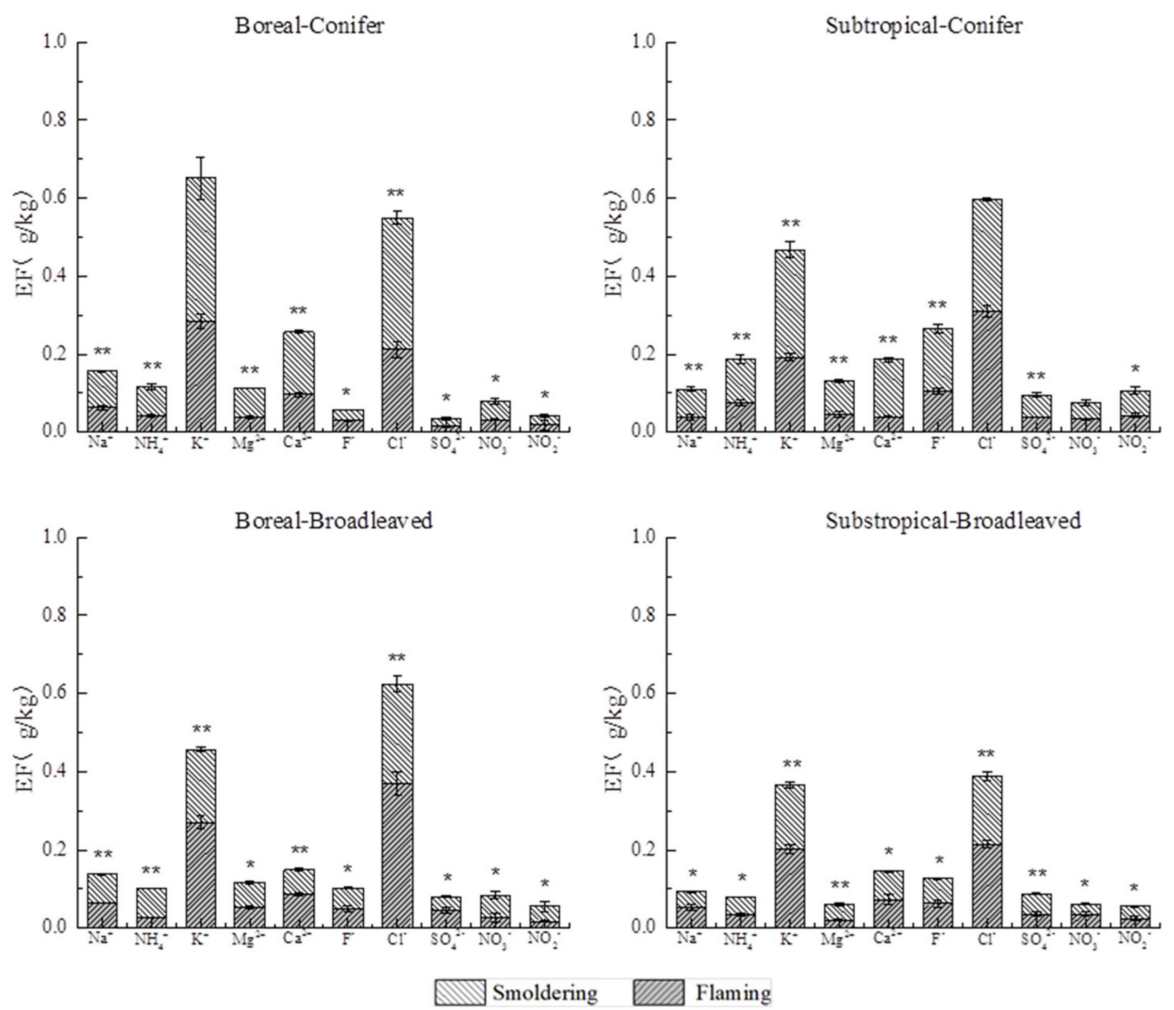

Figure 3. Comparison of emission factor $(\mathrm{g} / \mathrm{kg})$ of water-soluble inorganic ions in $\mathrm{PM}_{2.5}$ between smoldering and flaming stages of combustion of leaves and branches of each group of species within each region. Bars with asterisk $(* * p<0.01, * p<0.05)$ indicate significant differences between leaves and branches of conifer and broadleaved species within the boreal and sub-tropical region at the $5 \%$ probability level.

\subsection{Correlation Between Ionic Species in $P M_{2.5}$}

Significant correlations were observed between ionic species in $\mathrm{PM}_{2.5}$ (Table 4). For the boreal species, there were strong correlations $(\mathrm{r}>0.75)$ between $\mathrm{Na}^{+}$and $\mathrm{SO}_{4}{ }^{2-}$ and $\mathrm{NO}_{2}{ }^{-}$while the correlations between $\mathrm{Na}^{+}$and $\mathrm{F}^{-}$and $\mathrm{NO}_{3}{ }^{-}$were moderate $(\mathrm{r}=0.5-0.75) . \mathrm{NH}_{4}{ }^{+}$and $\mathrm{Mg}^{2+}$ were strongly correlated with $\mathrm{SO}_{4}{ }^{2-}, \mathrm{NO}_{3}{ }^{-}$and $\mathrm{NO}_{2}{ }^{-}$but moderately correlated with $\mathrm{F}^{-}$and $\mathrm{Cl}^{-}$. While $\mathrm{K}^{+}$ had no correlation with any of the anions, $\mathrm{Ca}^{2+}$ had a moderate correlation with $\mathrm{NO}_{3}{ }^{-}$. For sub-tropical species, $\mathrm{Na}^{+}$was moderately correlated with $\mathrm{NO}_{3}{ }^{-}$while $\mathrm{NH}_{4}{ }^{+}$was strongly correlated with $\mathrm{F}^{-}$, $\mathrm{Cl}^{-}$and $\mathrm{NO}_{2}{ }^{-}$. $\mathrm{K}^{+}$was moderately correlated with $\mathrm{NO}_{3}{ }^{-}, \mathrm{Mg}^{2+}$ was strongly correlated with $\mathrm{F}^{-}$ but moderately correlated with $\mathrm{Cl}^{-}$, and $\mathrm{Ca}^{2+}$ was strongly correlated with $\mathrm{SO}_{4}{ }^{2-}$ but moderately correlated with the rest of the anions. 
Table 4. Correlations between cations and anions of water-soluble inorganic ions in $\mathrm{PM}_{2.5}$ released during the burning of woody species.

\begin{tabular}{ccccccccccccc}
\hline \multicolumn{1}{c}{ Boreal Species } & \multicolumn{4}{c}{ Sub-Tropical Species } \\
\hline & $\mathbf{F}^{-}$ & $\mathbf{C l}^{-}$ & $\mathbf{S O}_{4}{ }^{2-}$ & $\mathbf{N O}_{3}{ }^{-}$ & $\mathbf{N O}_{2}{ }^{-}$ & & $\mathbf{F}^{-}$ & $\mathbf{C l}^{-}$ & $\mathbf{S O}_{4}{ }^{2-}$ & $\mathbf{N O}_{3^{-}}$ & $\mathbf{N O}_{2}{ }^{-}$ \\
\hline $\mathrm{Na}^{+}$ & $0.58^{*}$ & 0.18 & $0.82^{* *}$ & $0.53^{*}$ & $0.81^{* *}$ & $\mathrm{Na}^{+}$ & 0.14 & 0.02 & 0.41 & $0.53^{*}$ & 0.14 \\
$\mathrm{NH}^{+}$ & $0.58^{*}$ & $0.55^{*}$ & $0.79^{* *}$ & $0.80^{* *}$ & $0.86^{* *}$ & $\mathrm{NH}^{+}$ & $0.95^{* *}$ & $0.77^{* *}$ & 0.34 & $-0.10^{*}$ & $0.77^{* *}$ \\
$\mathrm{~K}^{+}$ & -0.23 & -0.06 & 0.18 & 0.19 & 0.07 & $\mathrm{~K}^{+}$ & 0.21 & 0.21 & 0.41 & $0.71^{* *}$ & 0.23 \\
$\mathrm{Mg}^{2+}$ & $0.69^{* *}$ & $0.54^{*}$ & $0.85^{* *}$ & $0.74^{* *}$ & $0.89^{* *}$ & $\mathrm{Mg}^{2+}$ & $0.78^{* *}$ & $0.57^{*}$ & 0.46 & -0.17 & -0.61 \\
$\mathrm{Ca}^{2+}$ & -0.28 & 0.36 & -0.23 & $0.57^{*}$ & 0.29 & $\mathrm{Ca}^{2+}$ & $0.55^{*}$ & $0.69^{* *}$ & $0.91^{* *}$ & $0.57^{*}$ & $0.70^{* *}$ \\
\hline \multicolumn{1}{c}{${ }^{*} p<0.05^{* *} p<0.01}$. \\
\end{tabular}

\section{Discussion}

Our result showed regional differences in emission factors of $\mathrm{PM}_{2.5}$ and total water-soluble ions; combustion of coniferous species from the boreal region emitted more $\mathrm{PM}_{2.5}$ while combustion of broadleaved species emitted more WSI than the subtropical region (Table 1). This difference could be related to the flammability and surface area-to-volume ratio of the fuel and inter-species variation in chemical composition in the biomass. Coniferous fuels have high flammability and energy content and often result in high $\mathrm{EFPM}_{2.5}$ [24,25]. Fuels with a large surface area-to-volume ratio require less heat for ignition, thereby favoring rapid and thorough flaming combustion. This is further evidenced in the present study where the heat of combustion was significantly higher for coniferous species $(19,149 \mathrm{~kJ})$ than the broadleaved species $(18,187 \mathrm{~kJ})$ (Table 1$)$. Thus, rapid combustion of species from the boreal region emitted a larger proportion of water-soluble ions than the subtropical region. Furthermore, significant differences in the EFWSI in particulate matter could be related to the chemical composition of the species [26-29]. The chemical composition of the biomass is influenced by nutrient biogeochemistry, which in turn varies between sites [30]. Similar emission differences in ambient smoke plumes between vegetation types were observed during controlled burning of the Brazilian cerrado vegetation and tropical rainforest [31].

The dominant ionic species in $\mathrm{PM}_{2.5}$ were $\mathrm{K}^{+}$and $\mathrm{Cl}^{-}$irrespective of the forest type and species burnt (Tables 2 and 3), which is in line with previously reported studies, which sampled smoke particles in the field and indoors $[13,31,32]$. The presence of $\mathrm{K}^{+}$as the major cationic species in $\mathrm{PM}_{2.5}$ is the result of primary production through volatilization of plant tissue material during the combustion process [13], and $\mathrm{K}^{+}$is often considered as a marker of biomass burning [11,12]. Emissions of all ionic species except $\mathrm{F}^{-}$was higher for the boreal than subtropical regions and emissions of $\mathrm{Na}^{+}, \mathrm{Cl}^{-}$, $\mathrm{SO}_{4}{ }^{2-}$ and $\mathrm{NO}_{3}{ }^{-}$were higher for broadleaved than coniferous species (Tables 2 and 3). This difference suggests that not only the species composition but also the geochemical differences between regions have an impact on the chemical composition of the fuel. Previous studies have shown that particulate matters released in smoke plumes during biomass burning were rich in $\mathrm{K}^{+}$and $\mathrm{Cl}^{-}[30,32]$ and the major water-soluble inorganic ions in $\mathrm{PM}_{2.5}$ during forest fire were $\mathrm{K}^{+}, \mathrm{Na}^{+}, \mathrm{NH}_{4}^{+}, \mathrm{Ca}^{2+}, \mathrm{Cl}^{-}, \mathrm{NO}_{3}^{-}$ and $\mathrm{SO}_{4}{ }^{2-}[30,33]$.

Our result also showed significant differences in EFs of WSI between combustion of leaves and branches (Figure 2). Generally, combustion of leaves emitted more ionic species in $\mathrm{PM}_{2.5}$ than branches. This could be related to high flammability of leaves [25] and structural differences between leaves and branches attributed to the denser structure and higher lignin content of branches than leaves [34]. The combustion stage had also a significant effect on emissions of ionic species in $\mathrm{PM}_{2.5}$; smoldering generally emitted more WSI than flaming combustion (Figure 3). High concentrations of water-soluble ions associated with increased release of particulate matter in the smoke are emitted under limited oxidation during smoldering. Guo et al. [13] reported a similarly higher EF of ionic species in $\mathrm{PM}_{2.5}$ during smoldering than flaming combustion while Liu et al. [12] demonstrated a higher content of total water-soluble ions in particulate matter released from the burning of dry branches during smoldering compared with flaming combustion. 
There were strong correlations between $\mathrm{Na}^{+}$and $\mathrm{SO}_{4}{ }^{2-}$ and $\mathrm{NO}_{2}{ }^{-}$, between $\mathrm{NH}_{4}{ }^{+}$and $\mathrm{SO}_{4}{ }^{2-}$, $\mathrm{NO}_{3}{ }^{-}$and $\mathrm{NO}_{2}{ }^{-}$as well as between $\mathrm{Mg}^{2+}$ and $\mathrm{SO}_{4}{ }^{2-}, \mathrm{NO}_{3}{ }^{-}$and $\mathrm{NO}_{2}{ }^{-}$for species from the boreal region (Table 4). This suggests that the PM could be composed of sodium, ammonium and magnesium sulphate and nitrate during burning of boreal species, while ammonium fluoride, ammonium chloride, ammonium nitrite, potassium nitrate, magnesium fluoride and calcium sulphate were major constituents of PM during the burning of subtropical species. We also calculated the cation to anion ratio, as this is considered to be a good indicator of the acidity of the particulate matter [3]. The ratio was 1.2 for the boreal forest and 0.98 for the subtropical forest. Thus, the particulate matter released during forest fires is neutral to slightly alkaline rather than acidic. The slight increase in $\mathrm{pH}$ associated with wet and dry deposition of WSI on the soil surface could possibly improve availability of nutrients, particularly phosphorus which is limited in subtropical forest ecosystems due to the acidic nature of the soil and fixation by iron and aluminum [35]. This, in turn, may favor growth and productivity of forests. However, the relatively high emission of $\mathrm{Cl}^{-}$compared to other anionic species calls for attention as wet deposition of chlorides may contribute to ecosystem acidification. As a whole, the study demonstrates that forest fire plays a minor role in the emission of acidic particulate matter.

\section{Conclusions}

Emission of $\mathrm{PM}_{2.5}$ and its water-soluble ionic component was higher in the boreal forest region than in the subtropical forest region, and coniferous species emitted more than broadleaved species. EFs of WSI were generally higher during combustion of leaves than branches and consistently higher during smoldering than during flaming combustion. The water-soluble ionic component in $\mathrm{PM}_{2.5}$ was dominated by $\mathrm{K}^{+}$and $\mathrm{Cl}^{-}$irrespective of the forest ecosystem and species. As a whole, our findings demonstrate that forest fire could contribute a considerable amount of water-soluble ions to atmospheric emission depending on the forest type and species. However, the cation to anion ratio is higher than 1.0, particularly for the boreal forest, suggesting that the particulate matter is alkalescent. Thus, forest fire in these regions may not contribute to ecosystem acidification through emissions of water-soluble ions. Our data are crucial for understanding emissions of WSI during different phases of forest fires and how different typologies of biomass can affect the profile of speciation emissions.

Author Contributions: Conceptualization, F.G.; methodology, F.G., Y.M., X.G., W.Z. and L.G.; validation, M.T. and F.G.; formal analysis, M.T., Y.M., X.G., W.Z. and L.G.; investigation, Y.M., X.G., W.Z. and L.G.; data curation, F.G.; writing — original draft preparation, M.T.; writing—review and editing, M.T., F.G.; visualization, Y.M.; supervision, F.G., M.T.; project administration, F.G.; funding acquisition, F.G.

Funding: The study was financially supported by the National Natural Science Foundation of China (Grant No. 31770697), the Asia-Pacific Network for Sustainable Forest Management and Rehabilitation (APFNet Climate Research Project) Phase II, and the Fujian Agriculture and Forestry University Funds for Distinguished Young Scholar (xjq201613).

Acknowledgments: We thank colleagues at the forestry college, Fujian Agriculture and Forestry University for their support during sample collection and indoor experiment.

Conflicts of Interest: The authors declare no conflict of interest.

\section{References}

1. Ito, A.; Penner, J.E. Historical emissions of carbonaceous aerosols from biomass and fossil fuel burning for the period 1870-2000. Glob. Biogeochem. Cycles 2005, 19, 273-280. [CrossRef]

2. Deng, C.R. Identification of Biomass Burning Source in Aerosols and the Formation Mechanism of Haze. Ph.D. Thesis, Fudan University, Shanghai, China, April 2011.

3. Deng, X.-L.; Shi, C.; Wu, B.-W.; Yang, Y.-J.; Jin, Q.; Wang, H.-L.; Zhu, S.; Yu, C. Characteristics of the water-soluble components of aerosol particles in Hefei, China. J. Environ. Sci 2016, 42, 32-40. [CrossRef] [PubMed]

4. Zhou, J.; Xing, Z.; Deng, J.; Du, K. Characterizing and sourcing ambient PM2.5 over key emission regions in China I: Water-soluble ions and carbonaceous fractions. Atmos. Environ. 2016, 135, 20-30. [CrossRef] 
5. Elias, P.E.; Burger, J.A.; Adams, M.B. Acid deposition effects on forest composition and growth on the Monongahela National Forest, West Virginia. Ecol. Manag. 2009, 258, 2175-2182. [CrossRef]

6. Fana, H.B.; Wang, Y.H. Effects of simulated acid rain on germination, foliar damage, chlorophyll contents and seedling growth of five hardwood species growing in China. Ecol. Manag. 2000, 126, 321-329. [CrossRef]

7. Hu, Y.; Bellaloui, N.; Tigabu, M.; Wang, J.; Diao, J.; Wang, K.; Yang, R.; Sun, G. Gaseous NO2 effects on stomatal behavior, photosynthesis and respiration of hybrid poplar leaves. Acta Physiol. Plant. 2015, 37, 39. [CrossRef]

8. Wang, H.L.; Zhu, B.; Shen, L.J.; Kang, H.Q. Size distributions of aerosol and water-soluble ions in Nanjing during a crop residual burning event. J. Environ. Sci. 2012, 24, 1457-1465. [CrossRef]

9. Park, S.S.; Sim, S.Y.; Bae, M.S.; Schauer, J.J. Size distribution of water-soluble components in particulate matter emitted from biomass burning. Atmos. Environ. 2013, 73, 62-72. [CrossRef]

10. Contini, D.; Cesari, D.; Genga, A.; Siciliano, M.; Ielpo, P.; Guascito, M.R.; Conte, M. Source apportionment of size-segregated atmospheric particles based on the major water-soluble components in Lecce (Italy). Sci. Total Environ. 2014, 472, 248-261. [CrossRef]

11. Li, J.; Pósfai, M.; Hobbs, P.V.; Buseck, P.R. Individual aerosol particles from biomass burning in southern Africa: 2, Compositions and aging of inorganic particles. J. Geophys. Res. Atmos. 2003, 108, 347-362. [CrossRef]

12. Liu, G.; Huang, K.; Li, J.H.; Xu, H. Chemical composition of water-soluble ions in smoke emitted from tree branch combustion. Environ. Sci. J. Integr. Environ. Res. 2016, 37, 3737-3742, (In Chinese with English abstract).

13. Guo, F.; Ju, Y.; Wang, G.; Alvarado, E.C.; Yang, X.; Ma, Y.; Liu, A. Inorganic chemical composition of PM2.5 emissions from the combustion of six main tree species in subtropical China. Atmos. Environ. 2018, 189, 107-115. [CrossRef]

14. Zheng, H.Q.; Chen, J.P.; Zhang, X.; Zhang, C.A.; Zhang, C.G.; Chen, H. Study on the forecast system of forest fire weather ranks in Fujian. Chin. J. Agrometeorol. 2001, 3, 38-44, (In Chinese with English abstract).

15. Wu, Z.; He, H.; Yang, J.; Liu, Z.; Liang, Y. Relative effects of climatic and local factors on fire occurrence in boreal forest landscapes of northeastern China. Sci. Total Environ. 2014, 493, 472-480. [CrossRef] [PubMed]

16. Guo, F.; Su, Z.; Wang, G.; Sun, L.; Lin, F.; Liu, A.Q. Wildfire ignition in the forests of southeast China: Identifying drivers and spatial distribution to predict wildfire likelihood. Appl. Geogr. 2016, 66, 12-21. [CrossRef]

17. Guo, F.; Selvaraj, S.; Lin, F.; Wang, G.; Wang, W.; Su, Z.; Liu, A.Q. Geospatial information on geographical and human factors improved anthropogenic fire occurrence modeling in the Chinese boreal forest. Can. J. For. Res. 2016, 46, 582-594. [CrossRef]

18. Guo, F.T.; Jin, Q.F.; Yang, X.J.; Liu, A.Q. An Air Compression System that Simulates the Burning of Wild Biomass. China Patent 2016211196373, 2017.

19. McMeeking, G.R.; Kreidenweis, S.M.; Baker, S.; Carrico, C.M.; Chow, J.C.; Collett, J.L., Jr.; Hao, W.M.; Holden, A.S.; Kirchstetter, T.W.; Malm, W.C.; et al. Emissions of trace gases and aerosols during the open combustion of biomass in the laboratory. J. Geophys. Res. Atmos. 2009, 114, 1-20. [CrossRef]

20. Akagi, S.K.; Yokelson, R.J.; Wiedinmyer, C.; Alvarado, M.J.; Reid, J.S.; Karl, T.; Crounse, J.D.; Wennberg, P.O. Emission factors for open and domestic biomass burning for use in atmospheric models. Atmos. Chem. Phys. 2011, 11, 27523-27602. [CrossRef]

21. Zhang, T.; Cao, J.J.; Tie, X.X.; Shen, Z.X.; Liu, S.X.; Ding, H.; Han, Y.M.; Wang, G.H.; Ho, K.F.; Qiang, J.; et al. Water-soluble ions in atmospheric aerosols measured in $\mathrm{Xi}^{\prime}$ an, China: Seasonal variations and sources. Atmos. Res. 2011, 102, 110-119. [CrossRef]

22. Zhang, J.; Smith, K.R.; Ma, Y.; Ye, S.; Jiang, F.; Qi, W.; Liu, P.; Khalil, M.A.K.; Rasmussen, R.A.; Thorneloe, S.A. Greenhouse gases and other airborne pollutants from household stoves in China: A database for emission factors. Atmos. Environ. 2000, 34, 4537-4549. [CrossRef]

23. Dhammapala, R.S. Evaluating Emission Factors of PM2.5, Selected PAHS and Phenols from Wheat and Kentucky Bluegrass Stubble Burning in Eastern Washington and Northern Idaho. Ph.D. Thesis, Washington State University, Pullman, WA, USA, August 2006.

24. Sandberg, D.V. Slash fire intensity and smoke emissions. In Proceedings of the Third National Conference on Fire and Forest Meteorology of the American Meteorological Society and the Society of American Foresters, Lake Tahoe, CA, USA, 2-4 April 1974. 
25. Reid, A.M.; Robertson, K.M. Energy content of common fuels in upland pine savannas of the south-eastern US and their application to fire behavior modelling. Int. J. Wildland Fire 2012, 21, 591-595. [CrossRef]

26. Kauffman, J.B.; Cummings, D.L.; Ward, D.E. Relationships of fire, biomass and nutrient dynamics along a vegetation gradient in the Brazilian cerrado. J. Ecol. 1994, 82, 519-531. [CrossRef]

27. Alves, C.A.; Gonçalves, C.; Pio, C.A.; Mirante, F.; Caseiro, A.; Tarelho, L.; Freitas, M.C.; Viegas, D.X. Smoke emissions from biomass burning in a Mediterranean shrubland. Atmos. Environ. 2010, 44, 3024-3033. [CrossRef]

28. Hosseini, S.H.; Urbanski, S.P.; Dixit, P.; Qi, L.; Burling, I.R.; Yokelson, R.J.; Johnson, T.J.; Shrivastava, M.; Jung, H.S.; Weise, D.R.; et al. Laboratory characterization of PM emissions from combustion of wildland biomass fuels. J. Geophys. Res. Atmos. 2013, 118, 9914-9929. [CrossRef]

29. Urbanski, S.P.; Hao, W.M.; Baker, S. Chemical composition of wildland fire emissions. In Developments in Environmental Science; Bytnerowicz, A., Arbaugh, M., Riebau, A., Andersen, C., Eds.; Elsevier: Amsterdam, The Netherlands, 2009; Volume 8, pp. 79-107.

30. Allen, A.G.; Miguel, A.H. Biomass burning in the Amazon: Characterization of the ionic component of aerosols generated from flaming and smoldering rainforest and savannah. Environ. Sci. Technol. 1995, 29, 486-493. [CrossRef]

31. Yamasoe, M.A.; Artaxo, P.; Miguel, A.H.; Allen, A.G. Chemical composition of aerosol particles from direct emissions of vegetation fires in the Amazon Basin: Water-soluble species and trace elements. Atmos. Environ. 2000, 34, 1641-1653. [CrossRef]

32. Echalar, F.; Gaudichet, A.; Cachier, H.; Artaxo, P. Aerosol emissions by tropical forest and savanna biomass burning: Characteristic trace elements and fluxes. Geophys. Res. Lett. 1995, 22, 3039-3042. [CrossRef]

33. Vicente, A.; Alves, C.; Calvo, A.I.; Fernandes, A.P.; Nunes, T.; Monteiro, C.; Almeida, S.M.; Pio, C. Emission factors and detailed chemical composition of smoke particles from the 2010 wildfire season. Atmos. Environ. 2013, 71, 295-303. [CrossRef]

34. Schmidl, C.; Bauer, H.; Dattler, A.; Hitzenberger, R.; Weissenboeck, G.; Marr, L.L.; Puxbaum, H. Chemical characterisation of particle emissions from burning leaves. Atmos. Environ. 2008, 42, 9070-9079. [CrossRef]

35. Chen, H.J.; Li, Y.Q.; Chen, D.D.; Zhang, Y.; Wu, L.M.; Ji, J.S. Soil phosphorus fractions and their availability in Chinese fir plantations in south China. For. Res. 1996, 9, 121-126.

(C) 2019 by the authors. Licensee MDPI, Basel, Switzerland. This article is an open access article distributed under the terms and conditions of the Creative Commons Attribution (CC BY) license (http://creativecommons.org/licenses/by/4.0/). 